\title{
Universal primers for exon-priming intron-crossing (EPIC) PCR on ribosomal protein genes in marine animals
}

\author{
Seinen Chow $\cdot$ Takashi Yanagimoto $\cdot$ Yoji Nakamura
}

Received: 2 June 2015/Accepted: 24 July 2015/Published online: 4 August 2015

(C) The Author(s) 2015. This article is published with open access at Springerlink.com

\begin{abstract}
Relatively conserved exon sequences among distant aquatic animal taxa (Copepoda, Echinodermata, and Teleostei) were determined for 12 ribosomal protein genes, and 19 primer pairs were designed for an exon-primed intron-crossing polymerase chain reaction strategy. The universal utility of these primers was evaluated in distant animal species (sea urchin, squid, crab, shark, and tuna). Fragment amplification was confirmed for at least three species for all primer pairs, and single fragment amplification was observed for at least one species in 16 primer pairs. Primer sets presented here may serve as an initial step for isolating singlecopy nuclear DNA sequences in a wide variety of marine animals.
\end{abstract}

Keywords Universal primers $\cdot$ Ribosomal protein genes $\cdot$ Intron $\cdot$ Single-copy nuclear loci $\cdot$ Marine animals

\section{Introduction}

Introns may be a good source for finding DNA polymorphisms in the eukaryotic genome as they rapidly accumulate mutations without greatly affecting gene function. Exon-primed intron-crossing (EPIC) polymerase chain reaction (PCR) has been developed and applied to find genetic polymorphisms in a wide variety of animals (Lessa 1992; Palumbi and Baker 1994; Corte-Real et al. 1994; Daguin et al. 2001; Chow and Takeyama 2000; Chow et al. 2007). Primers designed to target conserved areas may have a wide utility across a broad range of animal taxa (Chow and Hazama 1998; Hassan et al. 2002; Chow and Nakadate 2004; Pinho et al. 2010; Jennings and Etter 2011). The universality of the primers for EPIC PCR depends on the conservation of exonic sequences, and the efficiency of PCR amplification may be primarily affected by gene copy number, including pseudogenes. Genes encoding ribosomal proteins (RPs) may be highly suitable for designing universal primers, as RPs are the most highly conserved genes among eukaryotes and are typically encoded by a single gene (Wool 1979; Wool et al. 1995). Indeed, the coding sequences of RP genes are reported to be highly conserved among humans, fruit flies, and nematodes (Yoshihama et al. 2002). In this study, we designed 19 primer pairs in exons of 12 RP genes and demonstrated the universal utility of these primer pairs using samples of distantly related aquatic animal species.

S. Chow $(\bowtie) \cdot$ T. Yanagimoto $\cdot$ Y. Nakamura

National Research Institute of Fisheries Science, 2-12-4 Fukuura, Kanazawa, Yokohama, Kanagawa 236-8648, Japan

e-mail: chow@affrc.go.jp

T. Yanagimoto

e-mail: yanagimo@affrc.go.jp

Y. Nakamura

e-mail: yojnakam@affrc.go.jp 


\section{Materials and methods}

Eighty different ribosomal protein genes were mapped to human chromosomes (Uechi et al. 2001), and cDNA data for the homologous genes of the copepod (Lepeophtheirus salmonis, Acartia pacifica, or Calanus helgolandicus), sea urchin (Strongylocentrotus purpuratus or Paracentrotus lividus), and fish (Danio rerio or Ictalurus punctatus) were obtained from the GenBank database. RP genes that were not found in all three of these reference animal taxa were not analyzed. BLAST searches (Altschul et al. 1990) using these reference cDNA sequences against the draft genome sequences of the Pacific bluefin tuna (Thunnus orientalis; accession

Table 1 Sequences of primers for amplifying 19 introns of 12 ribosomal protein genes

\begin{tabular}{|c|c|c|c|c|c|}
\hline Pair & Gene & Primer & Orientation & Primer sequence $\left(5-3^{\prime}\right)$ & Distance $^{\mathrm{a}}$ \\
\hline \multirow[t]{2}{*}{ A } & $\mathrm{S} 2$ & $\mathrm{RPS} 2 \mathrm{exCF}$ & Forward & CCHGTNCCCAAGAAGCTGCT & 70 \\
\hline & $\mathrm{S} 2$ & RPS2exDR & Reverse & GGTYTCCTTCCASAGRTCAG & 43 \\
\hline \multirow[t]{2}{*}{ B } & $\mathrm{S} 3$ & RPS3ex1F & Forward & AAATCTCVAAGAAGAGRAAG & 2 \\
\hline & S3 & RPS3ex $2 R$ & Reverse & ACRCCGGAGTANCCATCCTC & 62 \\
\hline \multirow[t]{2}{*}{$\mathrm{C}$} & $\mathrm{S} 3$ & RPS3ex2F & Forward & GAGGATGGNTACTCCGGYGT & 53 \\
\hline & $\mathrm{S} 3$ & RPS3ex3R & Reverse & CKCTTCTGVACMACAGCGGT & 48 \\
\hline \multirow[t]{2}{*}{ D } & $\mathrm{S} 3$ & RPS3ex3F & Forward & ACCGCTGTKGTBCAGAAGMG & 30 \\
\hline & S3 & RPS3ex4R & Reverse & GTCGCAACCTTCTCAGCRTA & 24 \\
\hline \multirow[t]{2}{*}{$\mathrm{E}$} & $\mathrm{S} 3$ & RPS3ex4F & Forward & TAYGCTGAGAAGGTTGCGAC & 74 \\
\hline & $\mathrm{S} 3$ & RPS3ex5R & Reverse & AASCKCAGRACACCATARCA & 6 \\
\hline \multirow[t]{2}{*}{$\mathrm{F}$} & S14 & RPS14exAF & Forward & GCCTCMTTYAACGAYACCTT & 29 \\
\hline & S14 & RPS14exBR & Reverse & CKGTCRGCCTTYACCTTCAT & 30 \\
\hline \multirow[t]{2}{*}{ G } & S17 & RPS17exBF & Forward & AGWGGMATCTCCATCAARCT & 49 \\
\hline & $\mathrm{S} 17$ & RPS17exCR & Reverse & GGRTCRACCTCGATGATSTC & 18 \\
\hline \multirow[t]{2}{*}{$\mathrm{H}$} & $\mathrm{S} 23$ & RPS23exAF & Forward & TCACACGCCAARGGCATYGT & 15 \\
\hline & $\mathrm{S} 23$ & RPS23exBR & Reverse & ATRGCAGAGTTRGGCTGCTT & 14 \\
\hline \multirow[t]{2}{*}{ I } & $\mathrm{S} 23$ & RPS23exBF & Forward & AAGAACGGCAARAAGATCAC & 42 \\
\hline & $\mathrm{S} 23$ & RPS23exCR & Reverse & TGACCYTTACGWCCRAATCC & 26 \\
\hline \multirow[t]{2}{*}{$\mathrm{J}$} & $\mathrm{S} 27$ & RPS27exAF & Forward & GCTAARATYCARGAYAAGGA & 4 \\
\hline & $\mathrm{S} 27$ & RPS27exBR & Reverse & GTGCGKCCRTCYTCCAGCTG & 43 \\
\hline \multirow[t]{2}{*}{ K } & L3 & RPL3exAF & Forward & GGCTACAAGGCYGGYATGAC & 39 \\
\hline & L3 & RPL3exBR & Reverse & CAGTTYTTGTAGAAKCGACG & 149 \\
\hline \multirow[t]{2}{*}{$\mathrm{L}$} & L3 & RPL3exBF & Forward & GCGTCGMTTCTACAARAACT & 2 \\
\hline & L3 & RPL3exCR & Reverse & GTGAARGCCTTCTTCTYGGA & 9 \\
\hline \multirow[t]{2}{*}{ M } & L3 & RPL3exDF & Forward & CAAGGGWCACGGRTDCAAGG & 2 \\
\hline & L3 & RPL3exER & Reverse & GTCTTRCGGGGMAGCTTCTT & 25 \\
\hline \multirow[t]{2}{*}{$\mathrm{N}$} & L8 & RPL8exBF & Forward & AGTTCATCTACTGCGGCAAG & 37 \\
\hline & L8 & RPL8exCR & Reverse & ATGAYGGTDCCYTCAGGCAT & 5 \\
\hline \multirow[t]{2}{*}{$\mathrm{O}$} & L9 & RPL9exCF & Forward & RAACTTCYTGGGRGAGAAGT & 110 \\
\hline & L9 & RPL9exDR & Reverse & ACDGTGGTGGCYTGCTGGAT & 10 \\
\hline \multirow[t]{2}{*}{$\mathrm{P}$} & L11 & RPL11exAF & Forward & CARACGCCHGTCTTCTCCAA & 5 \\
\hline & L11 & RPL11exBR & Reverse & AAGGATCKYACAGTGTAGCG & 4 \\
\hline \multirow[t]{2}{*}{ Q } & L11 & RPL11exBF & Forward & CGCTACACTGTRMGATCCTT & 87 \\
\hline & L11 & RPL11exCR & Reverse & CCCARRTCGATGTGYTCCTG & 65 \\
\hline \multirow[t]{2}{*}{$\mathrm{R}$} & L17 & RPL17exAF & Forward & GAGWCMGCTCAGGCCATCAA & 132 \\
\hline & L17 & RPL17exBR & Reverse & TCGGCRCTCTTCTTRGGCCA & 8 \\
\hline \multirow[t]{2}{*}{$S$} & L24 & RPL24exBF & Forward & AGMCGCAARCACAAGAAGGG & 13 \\
\hline & L24 & RPL24exCR & Reverse & ACYTCAGGCTTCTGRTTCCT & 85 \\
\hline
\end{tabular}

${ }^{a}$ Number of nucleotides between $3^{\prime}$ end of the primers and start or end of the target introns 
nos. BADN01000001-BADN01133062 in the DNA Data Bank of Japan) (Nakamura et al. 2013) detected partial sequences of $31 \mathrm{RP}$ genes among 35 bluefin tuna scaffolds. For each of the 31 genes detected, a multiple sequence alignment was constructed by ClustalX version 1.83 (Thompson et al. 1997), and conserved regions suitable for designing universal primers were surveyed. Crude DNA samples of the long-spined sea urchin (Diadema savignyi), neon flying squid (Ommastrephes bartramii), golden crab (Chaceon granulatus),
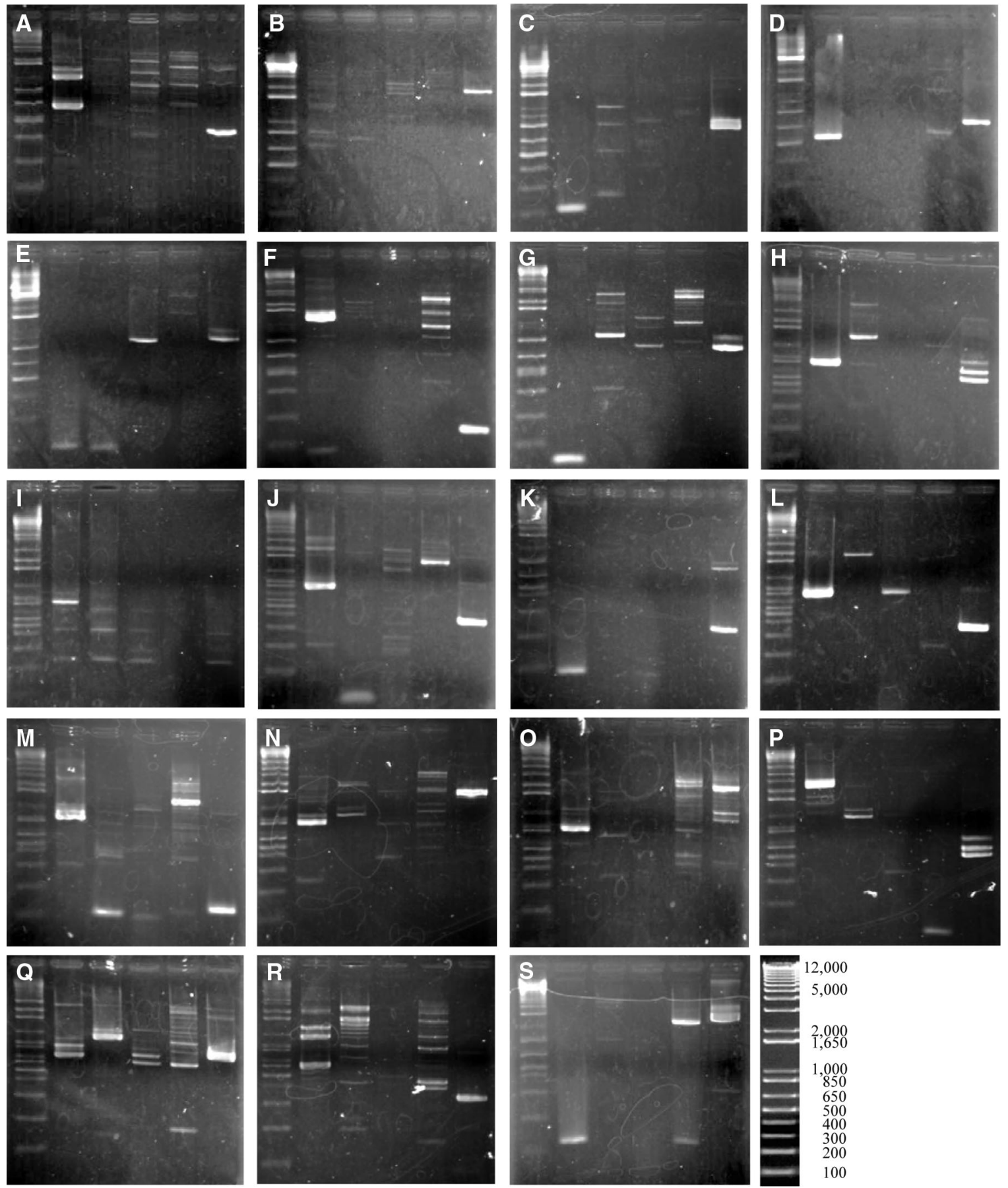

Fig. 1 Agarose gel electrophoresis images of the PCR products obtained by 19 primer pairs using a $55{ }^{\circ} \mathrm{C}$ annealing temperature. a-s Correspond to the primer pairs shown in Table 1. The left-most lane (1 st lane) of each gel image is the size marker (1 Kb Plus DNA Ladder, Invitrogen), and the 2nd-6th lanes correspond to long-spined sea urchin (Diadema savignyi), neon flying squid (Ommastrephes bartramii), golden crab (Chaceon granulatus), mako shark (Isurus oxyrinchus), and skipjack tuna (Katsuwonus pelamis), respectively 
mako shark (Isurus oxyrinchus), and skipjack tuna (Katsuwonus pelamis) archived in our laboratory were used for evaluating the universal utility of the primers. PCR amplifications were performed in a $12 \mu \mathrm{L}$ final volume containing $1 \mu \mathrm{L}$ of template DNA $(20-50 \mathrm{ng} / \mu \mathrm{L}), 1.2 \mu \mathrm{L} 10 \times$ buffer, $1 \mathrm{mM}$ of each deoxynucleotide phosphate (dNTP), $0.4 \mu \mathrm{M}$ of each primer, and 0.5 units of EX Taq polymerase (Takara, Japan). The same reaction conditions were applied for all primer pairs in which the reaction mixtures were preheated to $94{ }^{\circ} \mathrm{C}$
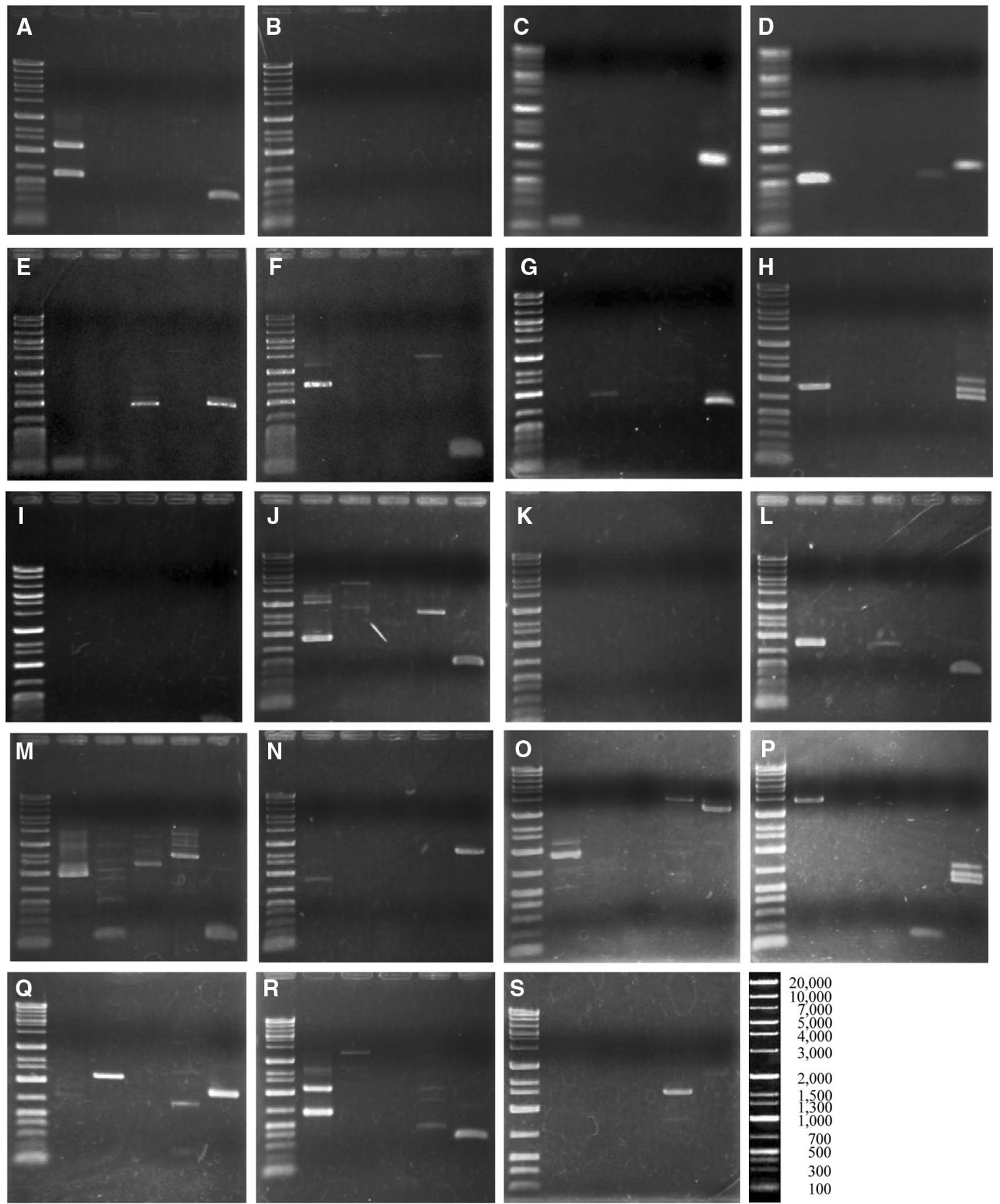

Fig. 2 Agarose gel electrophoresis images of the PCR products obtained by 19 primer pairs at a $58{ }^{\circ} \mathrm{C}$ annealing temperature. The left-most lane (1st lane) of each gel image is the size marker (Gene Ladder Wide 1, Wako), and the species used are the same as those in Fig. 1 
for $4 \mathrm{~min}$, followed by 35 amplification cycles $\left(94{ }^{\circ} \mathrm{C}\right.$ for $30 \mathrm{~s}, 55$ or $58{ }^{\circ} \mathrm{C}$ for $30 \mathrm{~s}$, and $72{ }^{\circ} \mathrm{C}$ for $50 \mathrm{~s}$ ), with a final extension at $72{ }^{\circ} \mathrm{C}$ for $7 \mathrm{~min}$. PCR products were electrophoresed on a $1.5 \%$ agarose gel (UltraPure Agarose, Invitrogen, Carlsbad CA), stained with ethidium bromide and photographed.

\section{Results and discussion}

Relatively conserved exon sequences among distant reference animal taxa were determined for 12 genes in which 19 primer pairs (A-S) were designed for EPIC PCR (Table 1). To design the primers, we adopted a primer length of 20 bases, a moderate GC content (approximately $50 \%$ ), and usually less than three degenerated bases, and because the conserved regions among the variety of taxa were not extensive, there were limited options for selecting primer positions.

At a lower annealing temperature $\left(55^{\circ} \mathrm{C}\right)$, amplification of single to multiple fragments ranging from approximately 100-4000 bp (fragments smaller than 100 bp were not counted) was observed in at least three taxa for each primer pair (Fig. 1). The number of amplified fragments decreased at the higher annealing temperature $\left(58{ }^{\circ} \mathrm{C}\right.$ ), to the extent that no amplified fragments were obtained for three primer pairs (Fig. $2 \mathrm{~b}, \mathrm{i}$, and $\mathrm{k}$ ). Amplification failure may be attributable to primer mismatch, large numbers of processed pseudogenes (Duvov and Perry 1984), and/or non-specific annealing, which may be responsible for multiple fragment amplification. At the higher annealing temperature, the number of primer pairs which amplified a single fragment was 13 pairs in tuna, followed by 8 in sea urchin, 6 in shark, 3 in squid, and only 2 in crab. Higher scores observed in tuna and sea urchin are reasonable, since RP gene data of teleost and sea urchin were used to design primers. The lowest result in crab may indicate distant relationship between copepod and decapod.

Two to three amplicons (13 in total) from five primer pairs (D, E, G, L, and Q) showing a single fragment amplification at the higher annealing temperature (Fig. 2) were selected and subjected to direct nucleotide sequencing using PCR primers. Partial or complete nucleotide sequences were successfully determined for eight (one each from primer pairs D, E, and G; two from L; and three from Q) out of 13 amplicons. Conserved exon sequences and expected exon-intron motifs for the respective RP genes were confirmed in six amplicons from D, E, G, and Q, whereas these were not determined in two amplicons from $\mathrm{L}$ due to the short distance between the primer annealing site and an intron (see Table 1). All sequences are available in DDBJ and GenBank under the accession numbers LC055480-LC055485, LC055565, LC055566.

Although intensive investigation into the optimal PCR conditions was not performed, amplification failure and multiple fragment amplification may be improved by controlling the annealing temperature or modifying the primer sequences for taxa of interest.

Thus, the present study offers new nuclear primers potentially applicable to a wide variety of marine animal taxa, which may be an initial step toward isolating single-copy nuclear DNA sequences in a wide variety of marine animals. Subsequent polymorphism detection may also provide a more informative database for genetic species identification and population study.

Acknowledgments This work was partially supported by a Grant-in-Aid for Scientific Research on Priority Areas (C) (No. 25450292) from the Ministry of Education, Science, Sports, and Culture, Japan.

Open Access This article is distributed under the terms of the Creative Commons Attribution 4.0 International License (http:// creativecommons.org/licenses/by/4.0/), which permits unrestricted use, distribution, and reproduction in any medium, provided you give appropriate credit to the original author(s) and the source, provide a link to the Creative Commons license, and indicate if changes were made.

\section{References}

Altschul SF, Gish W, Miller W, Myers EW, Lipman DJ (1990) Basic local alignment search tool. J Mol Biol 215:403-410 Chow S, Hazama K (1998) Universal PCR primers for S7 ribosomal protein gene introns in fish. Mol Ecol 7:1255-1256

Chow S, Nakadate M (2004) PCR primers for fish G6PD gene intron and characterization of intron length variation in the albacore Thunnuns alalunga. Mol Ecol Notes 4:391-393

Chow S, Takeyama H (2000) Nuclear and mitochondrial DNA analyses reveal four genetically separated breeding units of the swordfish (Xiphias gladius). J Fish Biol 56:1087-1098 
Chow S, Clarke S, Nakadate M, Okazaki M (2007) Boundary between the north and south Atlantic populations of the swordfish (Xiphias gladius) inferred by a single nucleotide polymorphism at calmodulin gene intron. Mar Biol 152:87-93

Corte-Real HBSM, Dixon DR, Holland PWH (1994) Intron-targeted PCR: a new approach to survey neutral DNA polymorphism in bivalve populations. Mar Biol 120:407-413

Daguin C, Bonhomme F, Borsa P (2001) The zone of sympatry and hybridization of Mytilus edulis and M. galloprovincialis, as described by intron length polymorphism at locus mac-1. Heredity $86: 342-354$

Duvov KP, Perry RP (1984) The gene family encoding the mouse ribosomal protein L32 contains a uniquely expressed introncontaining gene and an unmutated processed gene. Cell 37:457-468

Hassan M, Lemaire C, Fauvelot C, Bonhomme F (2002) Seventeen new exon-primed intron crossing polymerase chain reaction amplifiable introns in fish. Mol Ecol Notes 2:334-340

Jennings BM, Etter RJ (2011) Exon-primed, intron-crossing (EPIC) loci for five nuclear genes in deep-sea protobranch bivalves: primer design, PCR protocols and locus utility. Mol Ecol Res 11:1102-1112

Lessa EP (1992) Rapid survey of DNA sequence variation in natural populations. Mol Biol Evol 9:323-330

Nakamura Y, Mori K, Saitoh K, Oshima K, Mekuchi M, Sugaya T, Shigenobu Y, Ojima N, Muta S, Fujiwara A, Yasuike M, Oohara I, Hirakawa H, Chowdhury VS, Kobayashi T, Nakajima K, Sano M, Wada T, Tashiro K, Ikeo K, Hattori M, Kuhara S, Gojobori T, Inoue K (2013) Evolutionary changes of multiple visual pigment genes in the complete genome of Pacific bluefin tuna. PNAS 110:11061-11066

Palumbi SR, Baker CS (1994) Contrasting population structure from nuclear intron sequences and mtDNA of humpback whales. Mol Biol Evol 11:426-435

Pinho C, Rocha S, Carvalho BM, Lopes S, Mourão S, Vallinoto M, Brunes TO, Haddad CFB, Gonçalves H, Sequeira F, Ferrand N (2010) New primers for the amplification and sequencing of nuclear loci in a taxonomically wide set of reptiles and amphibians. Cons Genet Res 2:181-185

Thompson JD, Gibson TJ, Plewniak F, Jeanmougin F, Higgins DG (1997) The CLUSTALX windows interface: flexible strategies for multiple sequence alignment aided by quality analysis tools. Nucl Acid Res 25:4876-4882

Uechi T, Tanaka T, Kenmochi N (2001) A complete map of the human ribosomal protein genes: assignment of 80 genes to the cytogenetic map and implications for human disorders. Genomics 72:223-230

Wool IG (1979) The structure and function of eukaryotic ribosomes. Ann Rev Biochem 48:719-754

Wool IG, Chan Y-L, Gluck A (1995) Structure and evolution of mammalian ribosomal proteins. Biochem Cell Biol 73:933-947

Yoshihama M, Uechi T, Asakawa S, Kawasaki K, Kato S, Higa S, Maeda N, Minoshima S, Tanaka T, Shimizu N, Kenmochi N (2002) The human ribosoma protein genes: sequencing and comparative analysis of 73 genes. Genome Res 12:379-390 